\title{
Narrator in the Biographical Novels: A Typological Comparison
}

\section{Khajiyeva Feruza Melsovna}

Email: feruza11031979@mail.ru

\section{Doi:10.5901/ajis.2013.v2n9p357}

\section{Abstract}

The notion of the image of author was introduced to the subject of literature by the Russian critic V.Vinogradov in 20th of the last century. M.Bakhtin, R.Barthes, V.Khalizev and others developed the theory working out the types of image of author, voice, narrative techniques. Nowadays this problem is still being the center of attention of literary criticism and different approaches make clarities to it from various aspects.In the research we attempt to discuss about the image of author in the two biographical novels and show the similarity and diversity of styles being used. Through the typological comparison of American ("The Agony and the Ecstasy"(1961) by Irving Stone) and Uzbek ("RuziChoriyev's last will"(2008) by N. Normatov) novels we try to elicit author's point of view and give our interpretation.

Keywords: Biographical novel, point of view, narrator, limited-omniscient narrator, stream of consciousness.

\section{Introduction}

If the personages of a literary text are considered to be a form of expressing the idea of a work, the image of author is a an element which helps to cohere the separate parts into wholeness, to centralize the viewpoint thus constructing the literary work.

The notion of the image of author was introduced to the subject of literature by the Russian critic V.Vinogradov in $20^{\text {th }}$ of the last century. M.Bakhtin, R.Barthes, V.Khalizev and others developed the theory working out the types of image of author, voice, narrative techniques. Nowadays this problem is still being the center of attention of literary criticism and different approaches make clarities to it from various aspects.

According to M. Bakhtin, the author is inherent in all artistic works. He can be even, perceived in the art of painting though the attendee can't see him straightforwardly. The image of author is really existing, - he says, - and he differs from other images (personages), and there is the author who created him.(Bakhtin 2004, p. 306)

The theorists are still investigating the problem and now "Much of the work in narrative theory has involvedattempts to discriminate among different kinds of narrators (first person orthird person, objective or subjective, reliable or unreliable, so-called 'omniscient'or not, together with questionsconcerning his or her 'point of view', his or her 'voice' and so on). (Bennett, Royle, 57) It shows that the author creating his literary work intentionally choses a technique of narrating which defines the essence of the image of author.

\section{Analysis and Discussion 1: The Agony and the Ecstasy}

In the article we attempt to discuss about the image of author in the two biographical novels and show the diversity of narrative styles being used. Through the typological comparison of American ("The Agony and the Ecstasy" by Irving Stone) and Uzbek (RuziChoriyev's last will) novels we try to elicit author's point of view.

Irving Stone's biographical novel "The Agony and the Ecstasy" (1961) is about Michelangelo, sculptor, painter, architect, poet, and engineer who influenced on the development of the world art. A masterpiece in its own right, this novel offers a compelling portrait of Michelangelo's dangerous, impassioned love, and the God-driven fury from which he wrested the greatest art the world has ever known.

In his novel Irving Stone uses limited-omniscient point of view. The main character in the novel is Michelangelo and the author tells or unfolds the events from his point of view. In theepisodes and the scenes Michelangelo is the center of revelation and the reader sees the events and other personages from his point of view. Free indirect style helps the author combine the narration in the story which conduces to dynamic development of the plot thread and point of view of the main personage. 
Historical events, personages in the book are depicted to the reader the way Michelangelo sees and feels. Irving Stone uses this style in other of his biographical works too. This is his principle of creating a biographical novel. He always depicts historical reality in his personage's viewpoint.

For example setting in novel is depicted from the thirteen years old Michelangelo and his friend's viewpoint.

\begin{abstract}
"They made their way along the Via del Corso and saw on their right through the narrow slit of the Via dei Tedldini of the red tiled Duomo and after another block, on their left, the Palazzo dellaSignoriawith its arches, windows and crownings of its tan stone tower penetrating the faint sunrise blue of the Florentine sky. To reach the Ghirlandaio's studio they had to cross the square of the Old Market, where fresh beefs, cut down to the back bone and opened wide, hung on pulleys in front of the butcher's stall. From here it was but a short walk past the street of the Painters to the corner of the Via Dei Tavolini where they saw the open door of the Ghirlandaio's studio".(Stone, 476)
\end{abstract}

In excerpt above, the Florence streets are described from the point of view of the main hero. Both boys are going along the streets to the Ghirlandaio's studio in the aim of studying painting and on the way they saw and cross(underlined in excerpt) some places which the reader sees and crosses too. The author pays attention to the details his hero sees. Together with Michelangelo reader walks along the streets and becomes the witness of the following. Buildings, their arches and windows, blue Florentine sky, butchery, then Painter's street and at last the studio - all these unfold before the reader. I. Stone himself mentioned following: "In the biographical novel a basic tenet is that the author must stage his story as though it were happening right now; he may not emerge at intervals to inform the reader of what will happen two or twenty or two hundred years later. The reader may never be in possession of information which is not available to those who are acting out the day-by-day passion of their lives. The story must unfold for the reader even as the pageant of events unfolds for the participants."

With the help of this tenet author acquaints the reader with many contemporaries, famous artists, members of the Plato academy. The personage(historical person) of Rafael Sanzio's portray is depicted in the following way:

\begin{abstract}
"Michelangelo liked Rafael Sanzio immediately. He had a sensitive, patrician face, with wide, gentle, perceptive eyes, a full-lipped but disciplined mouth; long, luxuriant hair; fastidiously kept: as exquisite a face as Leonardo da Vinci's, yet in spite of a creamy skin, altogether manly. He carried himself with an expression of gracious warmth. His strong face was imbued with confidence, but there was not the slightest trace haughtiness. His clothes, too were as fine as Leonardo's with a white shirt and lace collar, richly colored cloak with tight- fitting cap to match; but he wore no jewels or scent. The beauty of the soft-spoken young man's face, figure and clothes did not make Michelangelo feel ugly, awkward or shabby, as Leonardo's inevitably did".(Stone 1981, p. 747)
\end{abstract}

Rafael Sanzio, twenty one year-old admirer of Michelangelo's art and beginner of his experience is introduced in excerpt above. The author does it in Michelangelo's point of view. Michelangelo likes the young man from acquaintance. In spite of his dressing like Lorenzo (Michelangelo disliked Lorenzo's fine dressing and accurate hair) Michelangelo appreciates Rafael's sincerity. Author enters the thoughts of his personage and describes his inner feelings, and thinks the way Michelangelo does.

Irving Stone describes historical events in the same way. XVI century political events in history of Florence are unfold before the reader in the main heroes reflection. Example:

\begin{abstract}
"With the fall, Florence became embroiled in an international dispute that could lead to the city-state's destruction. It was all happening, Michelangelo gathered, because Charles VIII, King of France, had built the first permanent army since Caesar's legions, constituting of twenty thousand trained and heavily armed men. He was now bringing that army across the Alps and into Italy to claim the Kingdom of Naples through inheritance. During Lorenzo's lifetime Charles VIII would have been too friendly to the Medici to threaten a march across Tuscany; if he had, Lorenzo's allies, the city-states of Milan, Venice, Genoa, Padua, Ferrara would have closed ranks to keep him out. But Piero had lost these allies. The Duke of Milan had sent emissaries to Charles, inviting him to Italy. The Medici cousins, who had been at Versailles for his coronation, assured the king that Florence awaited his triumphal entry".(Stone 1981, p. 622)
\end{abstract}

In the example above politically unstable situation is reasoned in Michelangelo's point of view. Lorenzo, the governor of Florence (Michelangelo's sponsor) died and after this there was a situation liable to failure or catastrophe in the territory. Further, Michelangelo considers that Lorenzo was in good relations with all of his allies. For this reason French king Charles VIII did not dare to attack Florence. But now situation was different, Michelangelo thinks, that is why French king was invading. He gathers that there are even supporters of French king among Medici. All these reader sees from Michelangelo's point of view and witnesses historical events too. 
As we see limited-omniscient point of view makes the personage closer to the reader. His point of view is prevailing in the story and liable to make reader trust the narration. Every time limited-omniscient narrator enters the thoughts of main personage and analyses the situation expressing attitude. Thus, natural historical atmosphere appears in the novel. Lively image of historical personage is formed.

\section{Analysis and Discussion 2: RuziChoriyev's Last Will}

In the process of analysis of the two mentioned biographical works we observed similarities and differences of them.

Uzbek novel "RuziChoriyev's Last Will" differs from I.Stone's, and at the same time it has analogies. The different point isin the narrating style. The similar point is also in type of narration. This is because the Uzbek novel has a special, genuine way of narrating. Different viewpoints have been used in it. The compositional-structural feature of it is complex.

Speaking about the plot of the work, it is dedicated to Uzbek artist. RuziChoriyev made an outstanding contribution to the development of national painting. His works mostly national in character are appreciated by people. The book offers a wide description of the painter's works and gives clarities to them. The biographical novel does not have chronological order. It is rather e descriptive and explanatory. Events come out from the topics discussed. In the first part of the novel the discussion is held by the narrator and the artist. The second part is a psychological one. It consists of premortal memories, thoughts and analytical lifesummaries of a hero. The third part consists of NodirNormatov's own recollections connected with painter and documents (letters, poem, articles of the painter) to help the reader to feel authenticity of the story.

Speaking about narrator, in the first part of the novel author directly creates his own image. He appears as anl narrator. He is a minor personage and a friend of the main hero. As a result of this kind of I narrator technique, a relationship between author and artist appears in the novel.

At the beginning of the novel the writer mentions about himself "At first I wanted to write from the name of Ruzi aka(Aka - brother. In Uzbek the word is used to show respect to elder people). Later, you see, everything what I knew, heard, observed began to flow in. As a result, the work composed on artist's and my own point of view. The aim, is the third point of view - reader's - about art, new opinion of life; important thing is this" (Normatov 2008, p. 4) This way writer himself enters the novel as a hero and writes his direct attitude to other personages and objective reality. He helps the reader to understand the world of art. The dialogue between the author and artist helps to comprehend the concept of RuziChoriyev's creative works. Obviously, the reader perceives it. The image of author helps to understand the artist's life and the world of fine arts.

As it was mentioned above, the first part of the work "Rainbow's home" is in the form of the dialogue, conversation between two friends. Author asks about landscape, painting, sketches and so on, and the painter answers the questions from his own viewpoint. The speech and viewpoint is rather dramatic. The words and the roles are clear and obvious. The writer distributed the words and opinion to the narrator and the image of painter."It was a starting day of the exhibition devoted to the genre of landscape in Tashkent. I visited and went to the artist's studio to find answers to some questions arisen in my mind...

- Ruzi aka, what is landscape in your understanding? What are the peculiar features of it?

- "What is landscape?" The answer to this question of one artist can be different from another's. It is natural. Why? The reason is that each creator has his own attitude to creativity, life and genre... But for me landscape it is not only place, but more than the whole universe, whole world. I would rather say it is the scenery of impressions in the heart. (Normatov 2008, p. 47)

Reader witnesses this kind ofconversation and gets information. Painter directly speaks and his attitude to the matter is perceived. It is a kind of publicist style.

Speaking about author's attitude in the novel, it is written in the chapters named "Notes from the authors dairy" and in the third part of the book. He tries to elicit his own viewpoint from the narration. Thus, itbecomes easy for the reader to see narrators opinion about the matter. From the next example it is possible to see the author's attitude. "One day I met RuziChoriyev mourning. Looking at me he said: Picasso died. I imitated his constant working. Now he is gone."- he said.

I was surprised at Ruzi aka's admiration for Picasso. Because I never saw any work in RuziChoriye's creation written under the influence of Picasso. But I am sure if his works transmitted into sculpture, ceramics and panel, the new features of his work will brilliantly shine out. Because RuziChoriyev's works are imbued with great monumental features like ancient wall paintings of Afrosiyob and Varakhsha.(Normatov 2008, p. 53) 
In this place the author is not an omniscient narrator, but comes as an art expert. He puts RuziChoriyev and his works on the same level as the world titans. He evaluates them highly. He compares his personage's works to those frescos on the Afrosiyob and Varakhsha walls, created in VII-VIII centuries AD, which are considered to be a part of Uzbek history. This way the special image of author in the novel combines painter's life events, images of the pictures, attitude to the artist's creation. He puts in order the facts. He interprets the essence of the pictures analyses them. As Ya.Kumok says "if a writer does not introduce the individuality of the author to his work, he will cuts the nerve of it."(Kumok, 28) This idea fully finds its reflection in N.Normatov's novel. It is materialized. That is to say the image of author "the nerve of the work" having its own image develops the events, analyses, interprets, explains- stands the same level as the personage.

Thus, we can say, in the first part of the book author uses dramatic point of view, which clarifies the roles, the speech of each character. For this purpose he uses I narrator to show his own attitude and understanding

An interesting feature of the novel is that the second book "The Last days of artist" has a different narrator that is limited-omniscient. In this point one can observe similarity with I.Stone's biographical novel. Limited-omniscient narrator enters the thoughts of painter and reads his memories. "Beginning of the January 2004. The weather was warm. Though the living-room was heated well, artist covered his feet and was lying on the sofa. His body was freezing but brain was working like a clock. "Why did this happen? Once when I was ready to die, God did not allow that? It seems time has come. But why did not I die then?" - thought the artist.(Normatov 2008, p. 94) Thus the recollections continue to flow. Stream of consciousness technique, inner speech develop the narration.

The other technique used by the author is "the chain of associations". Recollections are combined with the help of chain - the letters and photos from the old portfolio remind the main hero the past days. Associations connected with papers pictures, even some voices cohere into text wholeness. Example:

Artist took the newspaper, putting it into a black portfolio (His daughter Roksana had thrown it in the garage. He found and brought it back home.) foundMalinovskiy's letter. Malinovskiy was a general in times when Ruzi was in an army. Thirty years later he found him in Odessa. When he began reading the letter from Malinovskiy's the pain in his belly got to abate.(Normatov 2008, p. 126)

After narrator's speech, author introduces real Malinovskiy's letter. This way the other objects associate recollections and help the author to develop the narration.

\section{Conclusion}

From the above given examples and analyses of the image of author in the biographical novel it is possible to conclude that the narrator in the biographical novel, like in ordinary novel, can be of a different type. It can be omniscient, limitedomniscient, first person narrator or any other to combine the thoughts and the events, philosophy and ideas, in common the objective reality in which biographee had existed. Thus, he can observe, evaluate life events from different angles and increase the impact on the reader.

\section{References}

Andrew Bennett, Nicholas Royle "Literature, Criticism and Theory" - London, Pearson Longman, 2004. - p. 57

Stone Irving. Three complete novels. The Agony and the Ecstasy. New York. Avenel books.1981.P 622

BakhtinM. Author and Hero.-St-Petersburg, Azbuka, 2000. -P. 306.

Normatov N. Ruzi Choriyev's last will. - Tashkent,Sanát, 2008. - P.53.

Kumok Ya. Biography and biographer//Literary issues, 1973, №10. - Стр. 28. 